\title{
GENETIC ANALYSIS FOR SOOTY MOLD RESISTANCE AND HEART OF PALM YIELD IN Archontophoenix
}

\author{
Marilene Leão Alves Bovi ${ }^{1 *}$; Marcos Deon Vilela de Resende²; Luís Alberto Sáes ${ }^{1}$; Roberta \\ Pierry $\mathrm{Uzzo}^{1}$ \\ ${ }^{1}$ IAC - Centro de Horticultura, C.P. 28 - 13001-970 - Campinas, SP, Brasil. \\ EMBRAPA - Florestas, C.P. 319 - 83411-000 - Colombo, PR, Brasil. \\ *Corresponding author 〈mlabovi@iac.sp.gov.br>
}

\begin{abstract}
Archontophoenix palms, utilized both as ornamental species and as a source of high-quality heart of palm, are susceptible to sooty mold, a disease coupled with aphid infestation, which affects photosynthesis and causes unpleasant, darkish palm appearance. Scoring rates for sooty mold resistance and three growth traits were assessed under field conditions in 24 open-pollinated half-sibs families, 28 months after planting, aiming to identify genetic variability for sooty mold resistance; estimate genetic parameters for this trait and plant height, diameter and number of leaves; estimate genetic and phenotypic correlation for the four traits and evaluate selection methods for heart of palm production through multi-trait index selection based on growth traits. There were genetic differences among families for all traits. The low coefficient of variation for sooty mold $(9.48 \%)$ indicates that the visual rating method adopted was effective and feasible for comparing aphid plus sooty mold infestation levels in Archontophoenix. Narrow sense heritability estimates were low and medium for growth traits $(0.10,0.26$ and 0.26 for leaves number, plant diameter and height, respectively) and very high (0.91) for sooty mold resistance. Genetic correlation was found between sooty mold resistance and plant height. This positive relationship indicates that culling of very susceptible palms can be done possibily without interference in the follow up indirect selection for heart of palm yield. Some selection strategies were presented, showing that possible genetic gain could range from 6.23 to $11.83 \%$, depending on the selection method adopted and on the effective restriction of the population size.
\end{abstract}

Key words: Capnodium, Cerataphis, genetic gain, heritability, King palm

\section{ANÁLISE GENÉTICA PARA RESISTÊNCIA À FUMAGINA E PRODUÇÃO DE PALMITO EM Archontophoenix}

\begin{abstract}
RESUMO: Palmeiras do gênero Archontophoenix, utilizadas tanto como ornamentais quanto produtoras de palmito de qualidade, são susceptíveis à fumagina, doença associada à infestação por pulgões, que afeta a fotossíntese, o crescimento e a aparência das plantas. Foram avaliados a campo a resistência à fumagina conjuntamente com três caracteres associados ao crescimento em 24 famílias de meios-irmãos, 28 meses após o plantio, a fim de identificar a variabilidade genética para os caracteres resistência à fumagina, altura, diâmetro e número de folhas; estimar as correlações genotípicas e fenotípicas envolvendo esses quatro caracteres; e aplicar a estratégia de seleção usando o índice multiefeitos. Houve diferenças entre as famílias para os caracteres avaliados, sugerindo a possibilidade de seleção. O baixo coeficiente de variação observado para resistência à fumagina $(9,48 \%)$ indica que o método de avaliação adotado, baseado em escala de notas após observação visual, foi eficiente e prático para comparar níveis de infestação do complexo fungo+pulgão em palmeiras do gênero Archontophoenix. As estimativas da herdabilidade no sentido restrito foram baixas a médias para os caracteres relacionados ao crescimento $(0,10,0,26$ e 0,26 para número de folhas, diâmetro e altura da planta, respectivamente) e muito altas $(0,91)$ para resistência à fumagina. Correlação genética positiva foi observada entre resistência à fumagina e altura da planta, indicando que a eliminação de plantas muito susceptíveis pode ser feita sem interferência na seleção indireta para produção de palmito. A estratégia de seleção pelo índice multiefeitos (com ganhos genéticos esperados variando de 6,23 a 11,83\%) mostrou-se adequada para melhorar simultaneamente caracteres relacionados ao crescimento e à produção de palmito. Palavras-chave: Capnodium, Cerataphis, ganho genético, herdabilidade, palmeira real australiana
\end{abstract}

\section{INTRODUCTION}

Archontophoenix palms, commonly known as King palm and/or Bangalow palm, and worldwide utilized as ornamental (Jones, 1994; Lorenzi, 1996), have been recently cultivated for production of heart of palm (Tagliari, 1998; Bovi, 1998). They are precocious, easily cultivated palm trees (Bovi et al., 2001a) and have higher survival rate than Euterpe edulis Mart., a traditional heart of palm plant, largely and predatorily exploited in Bra- 
zilian natural forests (Orlande et al., 1996; Galetti \& Fernandez, 1998). The two main species of Archontophoenix (A. alexandrae Wendl. \& Drude and A. cunninghamiana (Wendl.) Wendl. \& Drude) have similar growth rate, heart of palm yield and overall quality (Bovi et al., 2001b). Therefore, either one can be cultivated, with economical and ecological advantages, in replacement to the extraction of Euterpe heart of palm.

Genetic variation for vegetative traits has been recently detected in an Archontophoenix breeding population (Bovi et al., 2003), suggesting the possibility of genetic improvement by selection. Unfortunately, like other palm species, Archontophoenix plants are subjected to aphid infestation (Bustillo \& Sanchez, 1977; Meerow, 1992; Enobakhare, 1994; Enobakhare \& Omogiate, 1999). The aphid Cerataphis brasiliensis Hempel (synonyms $C$. variabilis, C. palmae and C. fransseni) (Russell, 1996), causes direct feeding damage on palms and can vector plant viruses (Sumalde \& Calilung, 1982; Zipagan et al., 1995). The aphid also secretes honeydew, which acts as a growth medium for sooty mold. This is a superficial fungal disease caused by several fungi species from the Capnodium genus that establish a synergistic relationship with the sap-feeding insect and also with another fungi (Srivastava \& Thakre, 2000). Sooty mold appears on the leaf surface and is characterized by a conspicuous and unsightly black sooty deposit, consisting mainly of fungal biomass.

The complex composed by insect, saprophytic fungi and associated phytopathogenic organisms, is directly responsible for blocking incident radiation (Gausman \& Hart, 1974; Tedders \& Smith, 1976), specially wavelengths in the spectrum of primary photosynthesis (Smith \& Tedders, 1980). Heavy infestation decreases photosynthetic activity (Wood et al., 1988; Brink \& Hewitt, 1992; Kaakeh et al., 1992) and, consequently, plant growth and yield (Van Den Berg \& Greenland, 1997). In addition, in ornamental species, like King palms, sooty mold also compromises aesthetic qualities (Chauvel \& Fourot, 1997). Although there is chemical control for insect and fungi (Jalaluddin \& Mohanasundaram, 1990; Dharpure et al., 1994), its use is not feasible in mature plants, and should be avoided in palms ready to be harvested for heart of palm. Therefore, resistant plant material should be sought. The sooty mold developing on the honeydew excreted by the aphid has more serious effects than the direct feeding injuries (Srivastava \& Thakre, 2000) turning disease resistance the main breeding target. Because of the close cause and effect relationship, breeding for sooty mold resistance indirectly improves aphid resistance. In addition, sooty mold symptoms are easier to be rated than aphid symptoms or insect population density.
Plant resistance to the sooty mold complex was reported for other perennial species. (Sharma \& Badiyaka, 1991; Negi et al., 2000). In pecan, for example, sooty mold accumulation differed among cultivars (Sparks \& Yates, 1991). Therefore, pecan leaf surface morphology may be useful in selecting germplasm with reduced susceptibility to sooty mold accumulation. No related published research was found for palm species. Therefore, the objectives of this study were: (i) to identify genetic variation for sooty mold susceptibility in Archontophoenix palms; (ii) to estimate genetic parameters for this trait as well as for plant height, stem diameter and number of leaves; and (iii) to evaluate selection methods for heart of palm production through multi-trait index selection based on number of leaves, plant height and diameter.

\section{MATERIAL AND METHODS}

\section{Genetic material, statistical design and measurements}

The genetic material consisted of 24 open-polli-

nated, half-sibs families obtained from the Archontophoenix genus sampled in the east region of Santa Catarina, Brazil. The 24 families were classified in three groups according to their origin, although RAPD marker analysis revealed no genetic differences among them (Uzzo, 2001). Then all families were considered to belong to the same global population. Ten months after sowing, the plants were field established in PariqueraAçu, SP, Brazil ( $24^{\circ} 43^{\prime} \mathrm{S}, 47^{\circ} 53^{\prime} \mathrm{W}$; altitude $\left.25 \mathrm{~m}\right)$. The climate of the region is mesothermic, tropical, hot and humid, average annual temperature $22.1^{\circ} \mathrm{C}$, annual rainfall $1519 \mathrm{~mm}$, and evapotranspiration $1087 \mathrm{~mm}$ (Lepsch et al., 1990). The soil at the experimental area was a Xanthic Haploperox, with the following chemical properties at $0-20 \mathrm{~cm}$ depth: $\mathrm{pH}\left(\mathrm{CaCl}_{2}-0.01 \mathrm{~mol} \mathrm{~L}^{-1}\right) 4.04$, organic matter $20.45 \mathrm{~g} \mathrm{dm}^{-3}, \mathrm{P} 2.57 \mathrm{mg} \mathrm{dm}{ }^{-3}, \mathrm{~K}^{+} 1.42, \mathrm{Ca}^{2+}$ 7.53, $\mathrm{Mg}^{2+} 1.90, \mathrm{H}+\mathrm{Al}^{3+} 90.88 \mathrm{mmol}_{\mathrm{c}} \mathrm{dm}^{-3}$, and $11 \%$ base saturation of the CEC at $\mathrm{pH} 7.0$, determined according Raij et al. (1986).

The experiment was planted in $2 \times 1 \mathrm{~m}$ spacing, utilizing seedlings grown in polyethylene bags $(14 \mathrm{~cm}$ open diameter x $20 \mathrm{~cm}$ height) under nursery conditions ( $75 \%$ sun incidence). The subtrate was composed of soil and cow manure (3:1, in volume; with capacity for 1.26 $\mathrm{kg}$ or $1.3 \mathrm{~L}$ ) in accordance to the recommendation provided by Bovi (1998). The experiment was set out in a randomized complete block design with 24 treatments, three replications and 33 plants per single row plot. No limestone was applied to correct soil acidification. Superphosphate at a rate of $100 \mathrm{~g}$ per planting hole was applied. Mineral fertilization, $50 \mathrm{~g}$ per plant of NPK (20:5:20), was provided every three months. Growth was assessed periodically by measuring plant diameter and height, as well as leaf number, following standard palm 
procedures (Clement \& Bovi, 2000). Twenty eight months after planting, when plants were at their maximum growth rate, they were individually rated for sooty mold symptoms. The following rating scores were utilized, under natural infestation conditions: 1- all leaves with heavy infestation of sooty mold (severe damage); 2 - all leaves infected, except the spear leaf and the first fully expanded leaf (heavy damage); 3- at least one new leaf infected (moderate damage); 4- only old leaves infected (light damage); 5- completely without sooty mold (no damage).

\section{Genetic Parameters Estimation and Selection Methods}

Genetic and phenotypic parameters estimates were obtained for the traits plant diameter and height, leaf number and sooty mold, all at twenty eight months after planting. The genetic statistical software Selegen, (Resende et al., 1994) was used in all analysis. Narrow sense heritability coefficients associated to individual within block, individual within plot, plot and family effects were estimated following expressions provided by Resende \& Higa (1994) and assuming a mixed mating system, with $50 \%$ self pollination rate as indicated by the study of Bovi et al. (2003). The linear model for an individual observation in the progeny test was:

$Y_{i j k}=\mu+b_{j}+p_{i}+e_{i j}+d_{i j k}$

where: $Y_{i j k}=$ observation of plant $k$, of family $i$, in block $j ; \mu=$ general mean, fixed, $E(\mu)=\mu$ and $E\left(\mu^{2}\right)=\mu^{2} ; b j=$ block effect, fixed, $E\left(b_{j}\right)=0$ and $E\left(b_{j}^{2}\right)=b^{2} ; p_{i}=$ family effect, random, $E\left(p_{i}\right)=0$ and $E\left(p_{i}^{2}\right)=\sigma_{p}^{2} ; e_{i j}=$ plot effect, random, $E\left(e_{i j}\right)=0$ and $E\left(e_{i j}^{2}\right)=\sigma_{e}^{2} ; \quad d_{i j k}=$ within plot effect, random, $E\left(d_{i j k}\right)=0$.

The estimation of the variance components and heritability coefficients followed the sources of variation and expected mean squares (Table 1). The estimation of the genetic and phenotypic correlation followed a similar scheme of covariance analysis.

Regarding the effects of the linear model, the selection methods evaluated were: within family, among and within family, individual and multi-effects index selec-

Table 1 - Sources of variation and expected mean squares in the analysis of variance.

\begin{tabular}{|c|c|c|c|}
\hline $\begin{array}{l}\text { Sources of } \\
\text { variation }\end{array}$ & D.F. & M.S. & E(M.S.) \\
\hline Blocks & b- 1 & - & - \\
\hline Families & $\mathrm{p}-1$ & $\mathrm{M}_{\mathrm{S}} ._{1}$ & $1 / \widetilde{n} \sigma_{d}^{2}+\sigma_{e}^{2}+\mathrm{b} \sigma_{p}^{2}$ \\
\hline Residual & $(b-1)(p-1)$ & $\mathrm{M} \mathrm{S}_{2}$ & $1 / \tilde{n} \sigma_{d}^{2}+\sigma_{e}^{2}$ \\
\hline Within & $(\mathrm{N}-\mathrm{bp})$ & $\mathrm{M} \mathrm{S}_{3}$ & $\sigma_{d}^{2}$ \\
\hline
\end{tabular}

D.F. $=$ degrees of freedom; $b=$ number of blocks (replications); $\mathrm{p}=$ number of families; $\tilde{n}=$ number of plants per plot (harmonic mean); $\mathrm{N}=$ number of plants in the trial; $\sigma_{d}^{2}=$ within plot variance $\sigma_{e}={ }^{2}$ among plots variance; $\sigma_{p}^{2}=$ among families variance. tion. The optimal selection procedure (that maximizes the correlation between predictand and predictor) is given by the multi-effects index (Resende \& Higa, 1994):

$$
\begin{aligned}
& I=b_{1} d_{i j k}+b_{2} p_{i}+b_{3} e_{i j} \\
& I=b_{1}\left(Y_{i j k}-\bar{Y}_{i j}\right)+b_{2}\left(\bar{Y}_{i \cdot .}-\bar{Y} \ldots\right)+b_{3}\left(\bar{Y}_{i j}-\bar{Y}_{i . .}-\bar{Y}_{. j}+\bar{Y}_{\ldots} \ldots\right)
\end{aligned}
$$

The multi-effects index coefficients are:

$b_{1}=\hat{h}_{d}^{2}=\frac{\left(1-\rho_{g}\right) \sigma_{a}^{2}}{\sigma_{d}^{2}}=$ "Heritability" of the within plot effect;

$b_{2}=\hat{h}_{f}^{2}=\frac{1+(n b-1) \rho_{g}}{\frac{n b}{\sigma_{p}^{2}+\sigma_{e / b}^{2}+\sigma_{d}^{2} / n b}} \sigma_{a}^{2}=$ "Heritability" of the progeny effect;

$b_{3}=\hat{h}_{p}^{2}=\frac{\left[\left(1-\rho_{g}\right) / n\right] \sigma_{a}^{2}}{\sigma_{e}^{2}+\sigma_{d}^{2} / n}=$ "Heritability" of the plot effect,

where $\rho_{g}$ is the additive genetic correlation between individuals within family: $\rho_{g}=(1 / 4)$ for half-sibs and $\rho_{g}=$ $(1 / 2)$ for full-sibs; $n$ is the number of plants per plot; $b$ is the number of replications and $\sigma_{a}^{2}=\left(1 / \rho_{g}\right) \sigma_{p}^{2}$ is the additive genetic variance.

For the balanced case, the multi-effects index is equivalent to individual BLUP (animal model), as demonstrated by Resende \& Fernandes (1999).

The accuracy of the index is given by

$\hat{r}_{I a}=\left[\alpha_{1} \hat{b}_{1}+\alpha_{2} \hat{b}_{2}+\alpha_{3} \hat{b}_{3}\right]^{1 / 2}$

where:

$\alpha_{1}=(1-r) \frac{n-1}{n} ; \alpha_{2}=\frac{1+(n b-1) r}{n b} \frac{p-1}{p} ; \alpha_{3}=\frac{(1-r)}{n} \frac{p-1}{p} \frac{b-1}{b}$

In indirect selection for heart of palm production, the following multi-trait selection indexes were evaluated: (1) $\mathrm{H}_{1}=\mathrm{w}_{1}$ Diam $+\mathrm{w}_{2}$ Alt; (2) $\mathrm{H}_{2}=\mathrm{w}_{3}$ Diam $+\mathrm{w}_{4}$ Alt + $\mathrm{w}_{5}$ Nleaves, where Diam, Alt and Nleaves are the predicted (simultaneously) genetic values for plant diameter and height and number of leaves, respectively.

The $\mathrm{w}_{\mathrm{i}}$ weights were determined by $\left(w_{i}=\left(1 / \sigma_{v_{i}}\right)\right.$ $p_{i}$ ), where $\sigma_{y_{i}}$ is the phenotypic standard deviation of the trait and $\mathrm{p}_{\mathrm{i}}$ is the relative economic importance of the trait (Resende, 2002). The $\mathrm{p}_{\mathrm{i}}$ values were determined considering the phenotypic correlation of these three traits with heart of palm production, as provided by Bovi et al. (2001a). For index (1), the $p_{i}$ values where: $p_{1}=0.497$ and $\mathrm{p}_{2}=0.503$. For index (2) the $\mathrm{p}_{\mathrm{i}}$ values where: $\mathrm{p}_{3}=$ $0.362 ; \mathrm{p}_{4}=0.367$ and $\mathrm{p}_{5}=0.270$. 
The effective population size $\left(\mathrm{N}_{\mathrm{e}}\right)$ associated to selection in the breeding population was calculated by the following formula (Resende, 2002):

$$
N_{e}=\frac{2(2-S) p n}{(1+S)^{2} \frac{\sigma^{2}}{n}+(1+S)^{2} n+\left(3-2 S-S^{2}\right)}
$$

where $p$ is the number of families, $n$ is the number of individuals per family, $S$ is the selfing rate and $\sigma^{2}$ is the variance of $n$.

\section{RESULTS AND DISCUSSION}

The frequency distribution related to sooty mold resistance rating were: $5.52 \%$ in score 1 (severe damage); $37.86 \%$ in score 2 (heavy damage); $14.63 \%$ in score 3 (moderate damage); $11.41 \%$ in score 4 (light damage); and $30.36 \%$ in score 5 (no damage). Therefore, considering only this trait, it seems that selection intensity should be up to $30 \%$ in the studied population.

Results concerning the analysis of variance and genetic parameters estimates are presented in Tables 2 and 3 . The experimental coefficients of variation $(\mathrm{CVe} \%)$ were low for all studied variables, ranging from 8.11 to $14.24 \%$. This is an indicative of high experimental precision and good assessment criteria. The low CV found for sooty mold rate $(9.48 \%)$ indicates that the visual rating system adopted provided an effective and feasible method of comparing aphid+sooty mold infestation levels in Archontophoenix.

Family effects were obtained for all four traits, showing enough genetic variability for selection purposes
(Table 2). This corroborated the high levels of genetic variance revealed by the genetic coefficient of variation (Table 2) and additive genetic variance estimates (Table $3)$. Higher levels of genetic variance were presented for the traits sooty mold and plant height and diameter. The number of leaves showed low genetic variability, indicating low possibility to obtain genetic gain for this trait, at least at the considered age.

Estimates of the narrow sense heritability at several levels are presented in Table 4. The traits plant height and diameter presented a moderate level of individual heritability ( 0.265 and 0.264 , respectively), whereas the number of leaves showed low individual heritability (0.102). Heritabilities of similar magnitude were found earlier for other palm species for the same or related traits. For instance, Ohashi (1990) reported narrow sense heritability estimates for plant diameter and height of 0.29 and 0.11 , respectively, for half-sib families of Euterpe oleracea at 24 months after field planting. Nishikawa (1995) reported heritability estimates based on progeny means for pejibaye (Bactris gasipaes Kunth) varying from 0.29 to 0.13 for plant diameter and from 0.61 to 0.35 for leaf number, at 6 and 14 months after planting, respectively. The same author found that heritability estimates for plant height was moderate $(0.24)$. Working also with pejibaye, Farias Neto (1999) reported values from narrow sense heritabilities estimates for plant diameter and height of 0.30 and 0.37 , respectively, for 15 months old plants. Later on, utilizing a mixed model methodology (REML/BLUP), and plants with 26 months after field planting, Farias Neto \& Resende (2001) found narrow sense heritabilities estimates for plant diameter and height

Table 2 - Analysis of variance for the measured variables from Archontophoenix families grown at Pariquera-Açu, SP, Brazil.

\begin{tabular}{|c|c|c|c|c|c|}
\hline \multirow[t]{2}{*}{ Source of variation } & \multirow[t]{2}{*}{ G.L. } & \multicolumn{4}{|c|}{ Mean squares } \\
\hline & & Diameter & Height & Number of leaves & Sooty mold \\
\hline Blocks & 2 & 3719.1407 & 9891.5127 & 2.9617 & 1.4089 \\
\hline Families & 23 & $404.2804 * *$ & $828.2289 * *$ & $0.4822 * *$ & $3.4038 * *$ \\
\hline Residual & 46 & 87.8125 & 215.2889 & 0.2132 & 0.0964 \\
\hline Within plot & & 532.8432 & 990.8574 & 1.3072 & 0.7280 \\
\hline $\mathrm{CV}_{\mathrm{e}}(\%)$ & & 9.2368 & 14.7178 & 8.1132 & 9.4893 \\
\hline $\mathrm{CV}_{\mathrm{g}}(\%)$ & & 13.50 & 19.12 & 7.01 & 47.78 \\
\hline General mean & & 101.4361 & 99.6935 & 5.6911 & 3.2725 \\
\hline
\end{tabular}

**Significant at $P<0.01$ by $\mathrm{F}$ test.

Table 3 - Estimates of the variance components: among families $\left(\hat{\sigma}_{p}^{2}\right)$, within plot $\left(\hat{\sigma}_{d}^{2}\right)$, additive genetic $\left(\hat{\sigma}_{a}^{2}\right)$ and among plots $\left(\hat{\sigma}_{e}^{2}\right)$ for four traits in a test of 24 open-pollinated families of Archontophoenix at Pariquera-Açu, SP, Brazil.

\begin{tabular}{lrrrr}
\hline Trait & \multicolumn{1}{c}{$\hat{\sigma}_{p}^{2}$} & \multicolumn{1}{c}{$\hat{\sigma}_{d}^{2}$} & \multicolumn{1}{c}{$\hat{\sigma}_{a}^{2}$} & \multicolumn{1}{c}{$\hat{\sigma}_{e}^{2}$} \\
\hline Diameter & 105.4856 & 532.8432 & 187.5299 & 69.9480 \\
Height & 204.3134 & 990.8574 & 363.2237 & 182.0530 \\
Number of leaves & 0.0897 & 1.3072 & 0.1594 & 0.1693 \\
Sooty mold & 1.1024 & 0.7280 & 1.9599 & 0.0720 \\
\hline
\end{tabular}


of 0.10 and 0.18 , respectively. Ravindran et al. (1985) reported heritabilities estimates of 0.39 for plant diameter, 0.35 for plant height and 0.18 for leaf number in arecanut palm (Areca catechu L).

The sooty mold trait presented heritability of high magnitude (0.906) (Table 4), indicating that the genetic variation for sooty mold resistance is higher than the environment variation in the studied population. A similar study could not be found in literature. This appears to be the first attempt to estimate genetic parameters of sooty mold and aphid complex in palms. Heritability estimates for disease resistance of medium to high magnitude have been reported earlier for other plant species and other fungi (Borges \& Brune, 1981; Tan \& Tan, 1996).

Heritabilities at the level of family, within family and plot effects (Table 4) showed magnitudes coherent with the utility of them for the multi-effects index selection using all effects of the linear model. A comparison of several selection methods that could be applied in the studied population for each of the four traits is presented in Table 5. Multi-effects index seems to be the best selection method for number of leaves and plant height and diameter, with efficiencies over mass selection ranging from $34 \%$ to $80 \%$. For these traits, the among family component of the index contributed with high accuracy. For the trait sooty mold, the individual selection seems to be as good as multi-index selection. This can be explained by the very high magnitude of the individual heritability of the trait.

Table 4 - Narrow sense heritability estimates at levels: within family in a plot $\left(\hat{h}_{d}^{2}\right)$; among families $\left(\hat{h}_{f}^{2}\right)$; among plots $\left(\hat{h}_{p}^{2}\right)$ and on an individual basis within block $\left(\hat{h}_{i}^{2}\right)$ for four traits in a test of 24 openpollinated families of Archontophoenix grown at Pariquera-Açu, SP, Brazil.

\begin{tabular}{lcccc}
\hline Trait & $\hat{h}_{d}^{2}$ & $\hat{h}_{f}^{2}$ & $\hat{h}_{p}^{2}$ & $\hat{h}_{i}^{2}$ \\
\hline Diameter & 0.1540 & 0.7896 & 0.0313 & $0.2648 \pm 0.0600$ \\
Height & 0.1604 & 0.7465 & 0.0248 & $0.2637 \pm 0.0600$ \\
Number of leaves & 0.0533 & 0.5627 & 0.0110 & $0.1018 \pm 0.0400$ \\
Sooty mold & 0.8526 & 0.9779 & 0.2162 & $0.9059 \pm 0.1200$ \\
\hline
\end{tabular}

The estimates of the genetic and phenotypic correlation involving the four traits are presented in Table 6 . In general, the estimates showed low to moderate magnitudes. The only non-significant genetic correlation was between sooty mold and number of leaves. This is indicative that sooty mold rating was not biased by leaf number, a common problem when rating disease symptoms that consider non destructive leaf characteristics (e.g. area, size or number) specially at field conditions (Bellotti \& Kawano, 1980; Lamb \& Aldwinckle, 1980). The highest genotypic correlation was between plant diameter and number of leaves. Higher correlations between both traits were detected earlier in Euterpe, Bactris and Areca palms (Bovi et al., 1990; 1992; Nishikawa, 1995; Ravindran et al., 1985). The correlation estimates involving plant height and diameter and number of leaves, as well as their heritability estimates, were used in the construction of multi-trait index selection aiming to select indirectly for heart of palm production.

The highest genotypic correlation between sooty mold and vegetative traits (Table 6) was found for palm resistance to the fungi+aphid complex and plant height $(\mathrm{rg}=0.5493)$. This positive relationship between both traits indicates that discarding very susceptible palms can be done in that population without interference in the follow up selection aiming to production of heart of palm, done by direct (heart of palm weight) or indirect traits (plant diameter and height).

The actual selection in this population will be implemented in two phases: an initial thinning through within family selection, combining sooty mold resistance and the other traits, and a final selection based on the multi-effects index. For the first phase, where 20 best individuals of each family will be selected, results concerning to the two multi-trait index selection are presented in Table 7. In this initial selection procedure, screening and roughing for sooty mold susceptibility (ratings 1 and 2) will be done at a visual basis in field conditions, due to the high individual heritability of this trait (Table 5). The index (1) is a better choice as it predicted the highest genetic gain in the breeding objective, an improved heart of palm production. The index (2) is less efficient

Table 5 - Estimates of the weights used in the multi-effects index (as defined in the material and methods), individual narrow sense heritability $\left(\mathrm{h}^{2}\right)$, accuracy of selection by the methods of individual (Ac-in), family (Ac-f), within family (Acw) and multi-effects index selection (Ac-IM), as well as the relative efficiency of selection by the IME over the individual or mass selection (Effic) for four variables from Archontophoenix families grown at Pariquera-Açu, SP, Brazil.

\begin{tabular}{lcccccccccc}
\hline Trait & \multicolumn{10}{c}{$50 \%$ Selfing Rate } \\
\hline & $\mathrm{b}_{2}$ & $\mathrm{~b}_{1}$ & $\mathrm{~B}_{3}$ & $\mathrm{~h}^{2}$ & Ac-f & Ac-w & Ac-in & Ac-IM & Effic \\
Diameter & 0.790 & 0.154 & 0.031 & 0.265 & 0.655 & 0.255 & 0.515 & 0.703 & 1.365 \\
Height & 0.746 & 0.160 & 0.025 & 0.264 & 0.637 & 0.260 & 0.514 & 0.688 & 1.338 \\
Number of leaves & 0.563 & 0.053 & 0.011 & 0.102 & 0.553 & 0.150 & 0.319 & 0.573 & 1.796 \\
Sooty mold & 0.998 & 0.853 & 0.216 & 0.906 & 0.777 & 0.545 & 0.952 & 0.950 & 1.000 \\
\hline
\end{tabular}

Sci. Agric. (Piracicaba, Braz.), v.61, n.2, p.178-184, Mar./Apr. 2004 
Table 6 - Phenotypic (rp) and genotypic (rg) correlation coefficients and respectives standard error estimates, based on individual palm among the evaluated traits of 24 open-pollinated families from Archontophoenix palms grown at Pariquera-Açu, SP, Brazil.

\begin{tabular}{|c|c|c|c|c|}
\hline Trait & & Diameter & Height & Number of leaves \\
\hline \multirow[t]{2}{*}{ Sooty mold } & $\mathrm{rp}$ & -0.3008 & -0.0370 & -0.1630 \\
\hline & $\mathrm{rg}$ & $-0.3983 \pm 0.1040$ & $0.5493 \pm 0.0900$ & $-0.1158 \pm 0.1602$ \\
\hline \multirow[t]{2}{*}{ Diameter } & $\mathrm{rp}$ & & 0.8329 & 0.5742 \\
\hline & $\mathrm{rg}$ & & $0.4506 \pm 0.1300$ & $0.6329 \pm 0.1300$ \\
\hline \multirow[t]{2}{*}{ Height } & $\mathrm{rp}$ & & & 0.5540 \\
\hline & $\mathrm{rg}$ & & & $0.4585 \pm 0.1700$ \\
\hline
\end{tabular}

Table 7 - Expected genetic gain (\%) through selection of the 20 best individuals of each family by two multitrait index selection (as defined in the Material and Methods) involving growth and yield traits of Archontophoenix palms evaluated at Pariquera-Açu, SP, Brazil.

\begin{tabular}{lcc}
\hline Trait & Index (1) & Index (2) \\
\hline & \multicolumn{1}{c}{ Genetic } & Gain $(\%)$ \\
Heart of palm production & 3.80 & 2.87 \\
Diameter & 4.03 & 4.11 \\
Height & 6.12 & 5.87 \\
Number of leaves & - & 0.78 \\
\hline
\end{tabular}

Table 8 - Expected genetic gain (\%) for heart of palm yield through several selection methods by the multi-trait index selection (1) (as defined in the Material and Methods) involving yield traits of Archontophoenix palms evaluated at Pariquera-Açu, SP, Brazil. Two effective population sizes $(\mathrm{Ne})$ of the selected population were considered: 15 and 30 . Ntotal and nmax are the total of individuals selected and the maximum number of individuals selected by family, respectively.

\begin{tabular}{|c|c|c|c|c|c|c|}
\hline \multirow{3}{*}{$\begin{array}{l}\text { Selection } \\
\text { Methods }\end{array}$} & \multicolumn{6}{|c|}{ Expected genetic gain for heart of palm yield } \\
\hline & \multicolumn{3}{|c|}{ Option (1): $\mathrm{Ne}=15$} & \multicolumn{3}{|c|}{ Option (2): $\mathrm{Ne}=30$} \\
\hline & $\begin{array}{c}\text { Genetic } \\
\text { gain }\end{array}$ & nmax. & $\begin{array}{c}\mathrm{N} \\
\text { Total }\end{array}$ & $\begin{array}{c}\text { Genetic } \\
\text { gain }\end{array}$ & nmax. & $\begin{array}{c}\mathrm{N} \\
\text { Total }\end{array}$ \\
\hline $\begin{array}{l}\text { Multi-effects } \\
\text { index }\end{array}$ & 11.83 & 3 & 43 & 6.23 & 3 & 72 \\
\hline $\begin{array}{l}\text { Multi-effects } \\
\text { index }\end{array}$ & 11.76 & 2 & 31 & 6.67 & 2 & 48 \\
\hline $\begin{array}{l}\text { Among and } \\
\text { within family }\end{array}$ & 11.75 & 2 & 26 & - & - & - \\
\hline Within family & - & - & - & 6.67 & 3 & 72 \\
\hline Within family & - & - & - & 6.66 & 2 & 48 \\
\hline
\end{tabular}

probably because of low heritability of the trait number of leaves. The index (1) will provide $3.80 \%$ of genetic gain in heart of palm production, with $4.03 \%$ and $6.12 \%$ of gain in diameter and height, respectively.
For the second stage selection, only the index (1) will be applied. Results concerning the genetic gain optimization by restricting the effective population size to a minimum desired are presented in Table 8. Constraining the effective population size to 30 , provided no selection among families and the genetic gain from within family selection and multi-effects index selection were almost the same for all situations. In this case, the selection of the 72 individuals by any method, with a maximum of three individuals selected by family, is indicated. The higher number of individuals is preferred because it provides a higher number of open-pollinated families to be evaluated in the next generation of selection, allowing higher selection intensity in the next selection cycle.

With the effective size constrained to 15 , better options exist in terms of selection methods and genetic gains. In such case, a genetic gain of 11.83 can be obtained with the selection of the best 43 individuals by the multi-effects index selection method. The selection of the best 13 families with the best two individuals per family presents a similar gain, however, providing only 26 families for evaluation in the next cycle of selection.

The trait sooty mold will be used as a limiting one and could cause elimination of a selected individual for heart of palm production, if it does not present a reasonable level for sooty mold, as indicated by its predicted genetic value for this trait. Then, genetic values for that trait were predicted for all individuals and will also guide the actual selection.

\section{REFERENCES}

BELlOTTI, A.; KAWANO, K. Breeding approaches in cassava. In: MAXWELL, F.G.; JENNINGS, P.R. (Ed.) Breeding plants resistant to insects. New York: John Wiley \& Sons, 1980. p.313-335.

BORGES, R.C.G.; BRUNE, A. Estudo da herdabilidade quanto à resistência a Diaporthe cubensis em Eucalyptus grandis. Revista Árvore, v.5, p.115120, 1981.

BOVI, M.L.A. Cultivo da palmeira real australiana visando à produção de palmito. Campinas: Instituto Agronômico, 1998. 26p. (Boletim Técnico, 172).

BOVI, M.L.A.; SAES, L.A.; GODOY JR., G. Correlações fenotípicas entre caracteres não destrutíveis e palmito em pupunheiras. Turrialba, v.42, p.382-390, 1992. 
BOVI, M.L.A.; SAES, L.A.; SPIERING, S.H. Taxa de crescimento de duas espécies de palmeira real australiana. (Compact disc) In: CONGRESSO BRASILEIRO DE FISIOLOGIA VEGETAL, 8., Ilhéus, 2001. Ilhéus, $2001 b$.

BOVI, M.L.A.; RESENDE, M.D.V.; SPIERING, S.H. Genetic parameters estimation in King palm through a mixed mating system model. Horticultura Brasileira, v.21, p.93-98, 2003.

BOVI, M.L.A.; GODOY JR., G.; SPIERING, S.H.; CAMARGO, S.B Relação entre caracteres da planta e do palmito de açaizeiros. Bragantia, v. 49, p.69-81, 1990

BOVI, M.L.A.; SAES, L.A.; UZZO, R.P.; SPIERING, S.H. Adequate timing for heart of palm harvesting in King palm. Horticultura Brasileira, v.19, p.135-139, 2001a.

BRINK, T.; HEWITT, P.H. The relationship between the white powdery scale, Cribrolecanium andersoni (Hemiptera: Coccidae) and sooty mould an the effect on photosynthetic rates of citrus. Fruits, v.47, p.413-417, 1992

BUSTILlO, A.E.; SANCHEZ, G. Especies de Cerataphis (Homoptera: Aphididae), plagas en palmas y orquideas en Colombia. Revista Latinoamericana de Ciências Agrícolas, v.13, p.68-70, 1977.

CHAUVEL, G.; FOUROT, J. Aphid and honeydew in green spaces. In INTERNATIONAL CONFERENCE ON PESTS IN AGRICULTURE, Montpellier, 1997. Montpellier: ANPP, 1997. v.3, p.867-877.

CLEMENT, C.R.; BOVI, M.L.A. Padronização de medidas de crescimento e produção em experimentos com pupunheira para palmito. Acta Amazonica, v.30, p.349-362, 2000.

DHARPURE, S.R.; SHARMA, M.L.; RAI, H.S.; SANGAR, R.B.S. Chemical control of citrus blackfly, Aleurocanthus woglumi Ashby and sooty mould disease of citrus with conventional insecticides alone and in combination with fungicides. International Journal of Tropical Agriculture, v.12, p.273-277, 1994

ENOBAKHARE, D.A. Occurrence and distribution of Cerataphis palmae (Ghesquiere) (Homoptera: Pemphigidae) on Raphia palms in southern Nigeria. Insect Science and its Application, v.15, p.101-104, 1994

ENOBAKHARE, D.A.; OMOGIATE, B.W. Effects of feeding sites on fecundity and longevity of the palm aphid Cerataphis palmae Ghesquiere (Homoptera: Pemphigidae) on young dwarf coconuts. Nigerian Journal of Entomology, v.16, p.67-71, 1999.

FARIAS NETO, J.T. Estimativas genéticas em progênies de meios-irmãos de pupunheira. Boletim Pesquisa Florestal, v.39, p.109-117, 1999.

FARIAS NETO, J.T.; RESENDE, M.D.V. Application of the mixed model methodology (REML/BLUP) in variance components estimation and prediction of genetic values in peach palm (Bactris gasipaes). Revista Brasileira de Fruticultura, v.23, p.320-324, 2001.

GALETTI, M.; FERNANDEZ, J.C. Palm heart harvesting in the Brazilian Atlantic forest: changes in industry structure and the illegal trade. Journal of Applied Ecology, v.35, p.294-301, 1998

GAUSMAN, H.W.; HART, W.G. Reflectance of sooty mold fungus on citrus leaves over the 2.5 to 40 micrometer wavelength interval. Journal of Economic Entomology, v.67, p.479-480, 1974.

JALALUDDIN, S.M.; MOHANASUNDARAM, M. Efficacy of insecticides against coconut aphid Cerataphis variabilis in the nursery. Indian Coconut Journal, v.21, p.16-17, 1990.

JONES, D.L. Palms throughout the world. Washington: The Smithsonian Institution Press, 1994. 410p.

KAAKEH, W.; PFEIFFER, D.G.; MARINI, R.O. Combined effects of Spirea aphid (Homoptera, Aphididae) and nitrogen fertilization on net photosynthesis, total chlorophyll content, and greenness of apple leaves. Journal of Economic Entomology, v.85, p.496-506, 1992.

LAMB, R.C.; ALDWINCKLE, H.S. Breeding for disease and insect resistance in tree crops. In: HARRIS, M.K. (Ed.) Biology and breeding for resistance to arthropods and pathogens in agricultural plants. College Station: Texas A\&M University, 1980. p.546-560.

LEPSCH, I.F.; SARAIVA, I.R.; DONZELI, P.L.; MARINHO, M.A.; SAKAI, E.; GUILLAUMON, J.R.; PFEIFER, R.M.; MATTOS, I.F.A.; ANDRADE, W.J.; SILVA, C.E.F. Macrozoneamento das terras da região do rio Ribeira de Iguape, SP. Campinas: Instituto Agronômico, 1990. 181p. (Boletim Científico, 19).

LORENZI, H. Palmeiras no Brasil: exóticas e nativas. Nova Odessa Editora Plantarum, 1996. 303p.

MEEROW, A.W. Betrock's guide to landscape palms. Cooper City: Betrock Information System, 1992. 153p.
NEGI, S.S.; RAJAN, S.; KUMAR, R. Developing new mango varieties through hybridization. Acta Horticulturae, n.509, p.159-160, 2000.

NISHIKAWA, M.A.N. Seleção entre e dentro de progênies de meios irmãos de pupunha (Bactris gasipaes H.B.K.) Jaboticabal: UNESP/FCAV, 1995 89p. (Dissertacão - Mestrado).

OHASHI, S.T. Variabilidade genética de populações de açaizeiro (Euterpe oleracea Mart.) no estuário amazônico. Piracicaba: USP/ESALQ, 1990. 114p. (Dissertação - Mestrado).

ORLANDE, T.; LAARMAN, J.; MORTIMER, J. Palmito sustainability and economics in Brazil's Atlantic coastal forest. Forest Ecology and Management, v.80, p.257-265, 1996.

RAIJ, B.; QUAGGIO, J.A.; SILVA, N.M. Extraction of phosphorus, potassium, calcium and magnesium form soils by an ion-exchange resin procedure. Communications in Soil Science and Plant Analysis, v.17, p.549-566, 1986.

RAVINDRAN, P.N.; BAVAPPA， K.V.A.; PILLAI, R.S.N.; RAMACHANDER, P.R.; NAIR, M.K.; NAIR, B.P.; KUMAR, K.V. Mass pedigree selection in arecanut (Areca catechu L.). A case history on the application of the method in a perennial tree crop. Journal of Plantation Crops, v.13, p.44-55, 1985

RESENDE, M.D.V. de Genética biométrica e estatística no melhoramento de plantas perenes. Brasília: Embrapa Informação Tecnológica, 2002.975p.

RESENDE, M.D.V. de; HIGA, A.R. Maximização da eficiência da seleção em testes de progênies de Eucalyptus através da utilização de todos os efeitos do modelo matemático. Boletim de Pesquisa Florestal, v.28/ 29, p. 37-55, 1994.

RESENDE, M.D.V. de; FERNANDES, J.S.C. Procedimento BLUP individual para delineamentos experimentais aplicados ao melhoramento florestal. Revista de Matemática e Estatística, v.17, p.89-107, 1999.

RESENDE, M.D.V. de; OLIVEIRA, E.B. de; MELINSKI, L.C.; GOULART, F.S.; OAIDA, G.R. SELEGEN - Seleção Genética Computadorizada: manual do usuário. Colombo: EMBRAPA,CNPF, 1994. 31p

RUSSELL, L.M. Notes on Cerataphis brasiliensis and synonyms palmae, variabilis and fransseni (Homoptera: Aphididae), with a key to Cerataphis species living on palms and orchids. Proceedings of the Entomological Society of Washington, v.98, p.439-449, 1996.

SHARMA, I.M.; BADIYAKA, S.D. Relative occurrence of sooty mould on mango varieties in Himachal Pradesh. Plant Disease Research, v.6, p.71-74, 1991

SMITH, J.S.; TEDDERS, W.L. Light measurements for studying sooty mold growth on simulated pecan foliage. Transactions of the ASAE, v.23, p.481-484, 1980.

SPARKS, D.; YATES, I.E. Pecan cultivar susceptibility to sooty mold related to leaf surface morphology. Journal of American Society for Horticultural Science, v.116, p.6-9, 1991

SRIVASTAVA, V.K.; THAKRE, R.P. Synergism and antagonism among the fungi grown in honeydew secretion on leaf surface of Nagpur mandarin. Indian Phytopathology, v.53, p.193-196, 2000.

SUMALDE, A.C.; CALILUNG, V.J. Life history of Cerataphis palmae Ghesquiere (Pemphigidae, Homoptera) on coconut. Philippine Entomologist, v.5, p.273-290, 1982.

TAGLIARI, P.S. Palmeira real impulsiona produção de palmito em Santa Catarina. Agropecuária Catarinense, v.11, p.61-65, 1998.

TAN, H.; TAN, A.M. Genetic studies of leaf disease resistance in Hevea. Journal of Natural Rubber Research, v.11, p.108-114, 1996.

TEDDERS, W.L.; SMITH, J.S. Shading effect on pecan by sooty mold growth. Journal of Economic Entomology, v.69, p.551-553, 1976.

UZZO, R.P. Avaliação agronômica e caracterização molecular (RAPD) de famílias de palmeira real australiana (Archontophoenix spp) visando à produção de palmito. Campinas: Instituto Agronômico, 2001. 60p (Dissertação - Mestrado).

VAN DEN BERG, M.A.; GREENLAND, J. Classical biological control of Aleurocanthus spiniferus (Hem.: Aleyrodidae), on citrus in southern Africa. Entomophaga, v.42, p.459-465, 1997.

WOOD, B.W.; TEDDERS, W.L.; REILLY, C.C. Sooty mold fungus on pecan foliage suppresses light penetration and net photosynthesis. HortScience, v.23, p. $851-853,1988$

ZIPAGAN, M.B.; PACUMBABA, E.P.; ORENSE, J.C. Insects significantly occurring on cadang-cadang and disease-free areas. Philippine Journal of Crop Science, v.17, p.S46, 1995. Supplement.

Received May 22, 2003

Accepted January 28, 2004 